\title{
地盤沈下が沈静化した後の地下水管理のあり方*
}

\author{
德永朋祥 ${ }^{* *}$

\section{Groundwater management after the cessation of land subsidence: Lessons learnt from the Tokyo Metropolitan Area}

\author{
Tomochika TOKUNAGA**
}

\section{1.はじめに}

日本国内では，七大公害の一つである地盤沈下 が広範に発生し，その対策に多くの努力が払われ てきたことはよく知られた事実である。例えば, 首都圈では, 第二次世界大戦終戦後, 高度経済成 長期にかけて，大規模な地下水揚水や東京ガス田 からの水溶性天然ガス採取による地盤沈下の問題 が発生しており，その対策として地下水揚水規制 や水溶性天然ガス鉱業権の行政による買い取り等 が行われ, 地盤沈下の抑制と被圧带水層中の急 速な水理ポテンシャルの回復が達成された（例 えば, 遠藤ほか, 2001)。現在では, 水理ポテン シャルの回復に伴う地下構造物等への負荷の増大 に代表される新しい問題を抱えつつあり（例え ば, 清水・鈴木, 2005), その対策や適切な地下 水管理に向けた検討が必要となってきている。地 下水は，地面の下に広く分布して扔り，比較的容 易に揚水し利用することが可能であることが多い ため, 平常時利用のみならず大震災等の緊急時水 源としての意味を持つ重要な水資源となり得る が, 現実には, 地下水利用に関する合意形成や適
切なマネジメント方法の構築といった課題が残さ れている。最近では, 社会の将来的なあり方につ いて様々な立場からの議論を通じ, 社会的な合意 を得ながら計画を立案し，実践することが望まれ ていること（例えば, 小林, 2007）を考えると, 地下水の持続可能性の保障や, 地盤沈下に代表さ れる問題を回避しつつ適切に地下水を利用するこ との可能性, 地域社会との協働としての地下水管 理のあり方について議論をし, 方向性を示してい くことが必要になっていると思われる。本稿で は, これらの観点も念頭に置きつつ, ありうる地 下環境管理の方策に向けて私見を述べてみたい。

\section{2. 地盤沈下とその鎮静化の経緯一東京を例に してー}

図 1 は, 東京都市圈の被圧带水層中に設置した 井戸内の水位変化を示した図である（遠藤ほか, 2001)。ちなみに，この間に扔ける不圧帯水層の 水位変化はそれほど大きくないとされている（川 島, 2001)。ただし, 武蔵野台地の一部では, 不 圧帯水層と被圧帯水層の水理的な連続性が認めら

* シンポジウム「地盤沈下の現状から見る今後の地下水管理」（主催：公益社団法人 日本地下水学会）にて講演

** 東京大学大学院新領域創成科学研究科環境システム学専攻

Department of Environment Systems, the University of Tokyo 


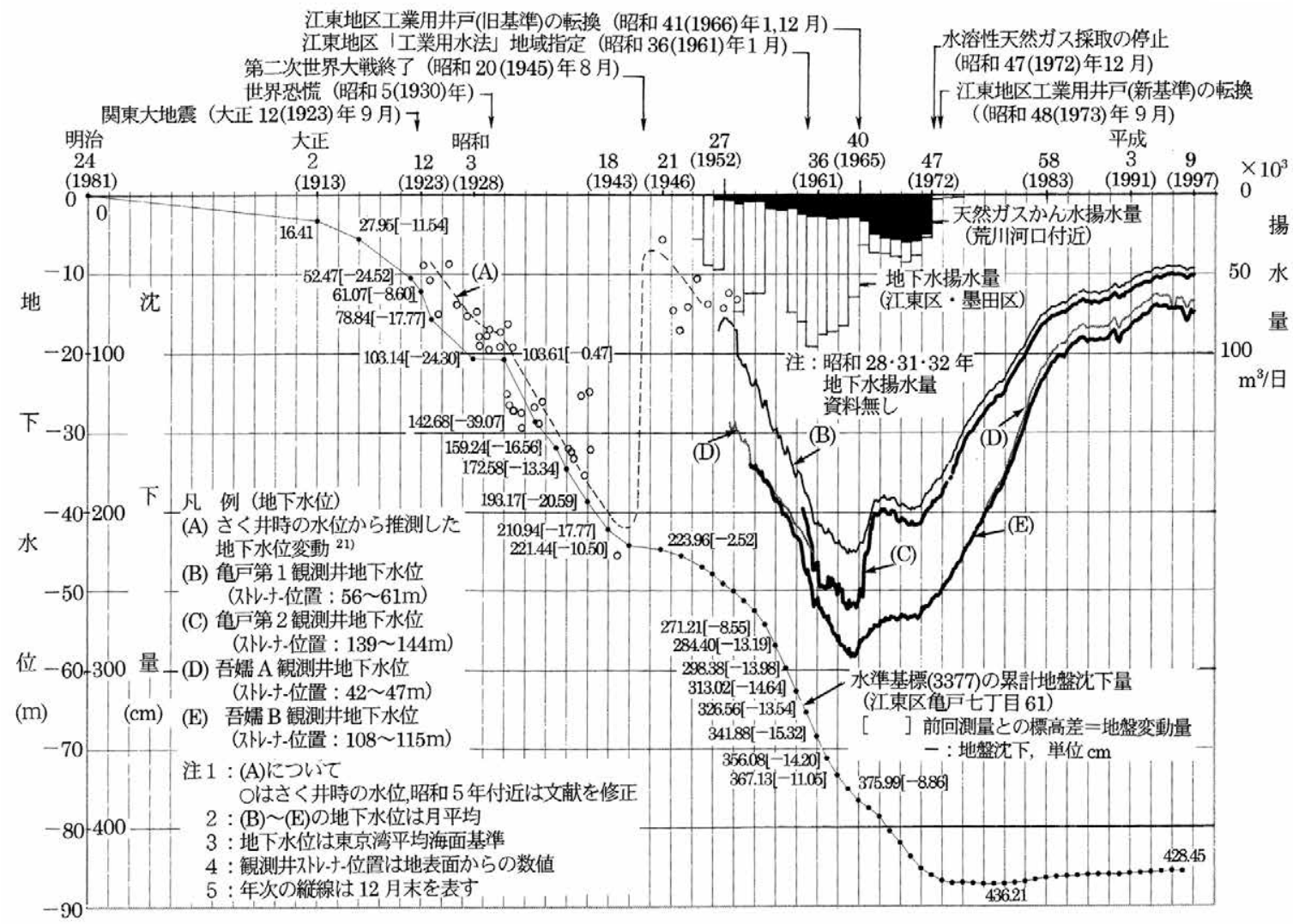

図 1 東京都市域における地下水・天然ガスかん水の揚水量と被圧帯水層に設置した観測井の井戸内水位, 地盤沈下量 の推移（遠藤ほか，2012）。なお，明治 24 年の下の年号は 1891 年の誤植である。

れる地域があること（榧根，1994）には注意を払 う必要がある。これに関連した事象として, 武蔵 野台地上にある井の頭池等いくつかの池の枯渴 は，揚水に伴う被圧带水層中の水理ポテンシャル 低下によって引き起こされた不圧帯水層から被圧 帯水層への地下水供給の増加による不圧帯水層の 水位低下により，湧水が消滅していったためであ るとされている（守田，2012）。

図 1 に示されている被圧帯水層中の水理ポテン シャルの低下の結果，大規模な地盤沈下が発生す る事態になった。その実態は図 2 に示される地 盤高分布に顕著に表れている（東京都建設局, 2004）。一度発生した地盤沈下は, 地下水の回復 に伴うわずかな地盤高の上昇が見られる場合はあ るものの, 全体としては地盤高がほとんど回復し ないため, 東京の下町低地ではいわゆる「ゼロ メートル地帯」が広く分布することとなった。例 えば, 図 1 に示されているように, 江東区亀戸で
は，明治時代と比較すると 4 メートルを超える地 盤沈下が起こったことがわかる。

これらの問題への対策として，図 1 に見られる ように，東京都などでは，地下水使用の規制を 行っている。その結果, 被圧带水層中の井戸内水 位は急激に回復し，地盤沈下も抑制された。最近 ではわずかではあるが，地表面の上昇が認められ る場合も出てきている（図 1)。このように，地 下水利用の規制によって, 地盤沈下等の問題が解 決されてきたことがわかる。なお，このような地 下水利用制限の実現のためには，利根川上流域に 掞ける水源開発等の事業の実施による水源転換が 行われたことを忘れてはいけない。

最近では, 地下水揚水が行われていた時代に構 築された地下構造物への漏水や構造物の変形, 浮き上がりといった新たな問題が発生してきて いることも知られており（例えば，清水・鈴木， 2005），この問題に対処するための投資も多額に 


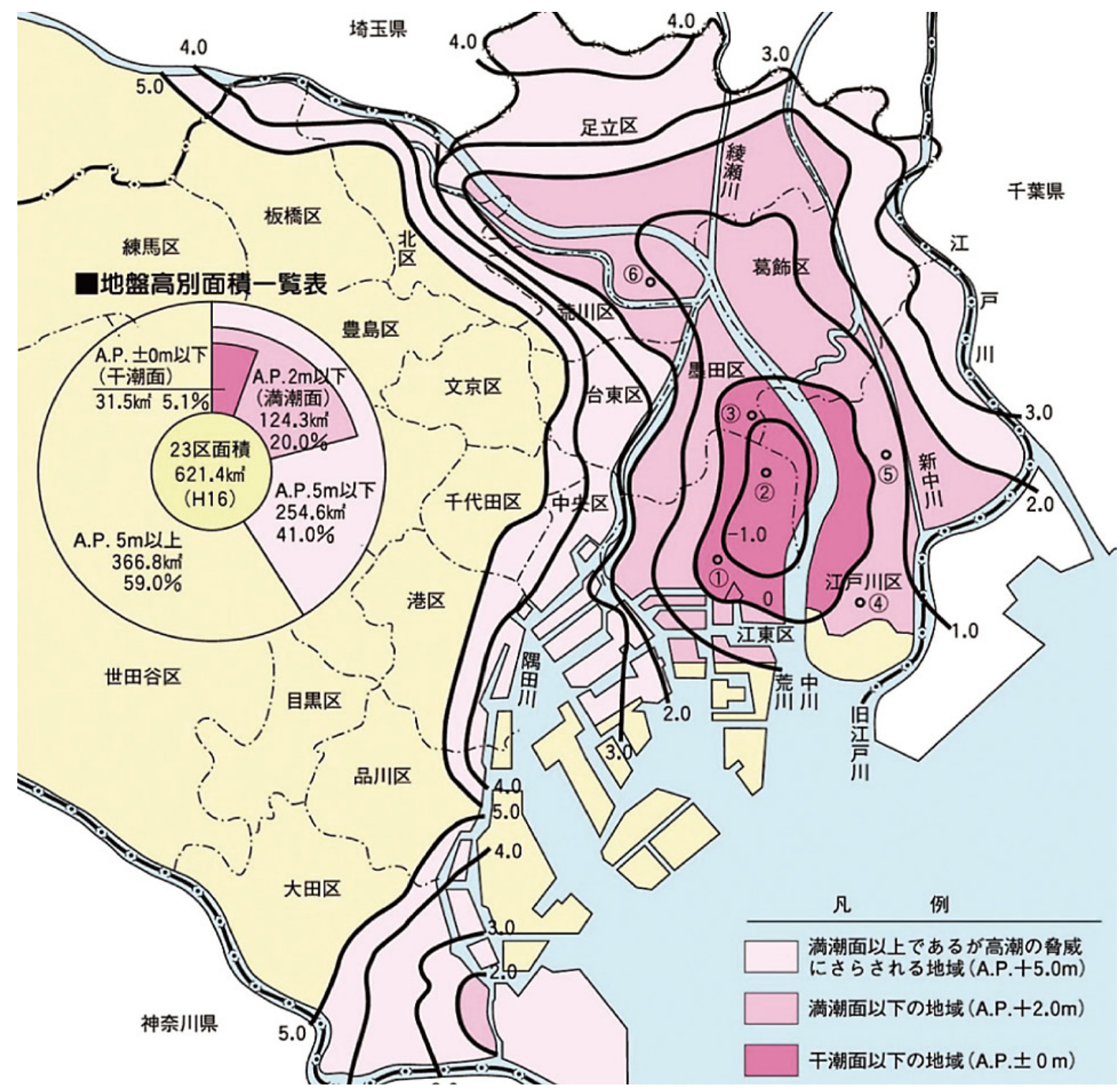

図2 東京下町低地の地盤高分布（東京都建設局, 2004）。

及ぶことが少なくなく, 軽視できない問題となっ ていることも事実である。

\section{3. 地盤沈下が起こった時期の加圧ユニット（難} 透水性層）の水理ポテンシャル変化

よく知られているように, 被圧帯水層から揚水 を行うと，その上下に位置する難透水性層からの 水の絞りだしが発生する。特に, 東京の下町低地 のように，まだ十分に固結していない地層中で は，粘土を主体とする難透水性層は，带水層を構 成する砂や㗂を主体とする地層よりも軟らかく,
水が絞りだされることによって大きく変形し，大 規模な地盤沈下が発生することとなる。従って, 地盤沈下の検討を詳細に行うためには，帯水層内 の水理ポテンシャルだけではなく，難透水性層中 の水理ポテンシャル（もしくは間隙水圧）の経時 変化を知ることが重要になってくる。

遠藤 · 小笠原 (1976) や廣瀬ほか (2004）の検 討に始まり，デー夕は限られているものの，東京 における難透水性層中の水理ポテンシャルの経時 変化の評価がなされている事例が存在する (Aichi and Tokunaga, 2007; 愛知, 2008)。ここでは, 被 圧带水層からの揚水過程において, 難透水性層で 
ある泥質層内の間隙水圧変化が帯水層のそれに比 べて遅れていることが指摘されている（図３）。

図 3 に見られる状況は, 我々が今後の地下水利 用や保全, 地盤沈下防止を検討するうえで多くの 示唆を与えている。一般に, 難透水性層である泥 質層の圧密は, 圧密降伏応力よりも有効応力が大 きくなることによって発生すると考えられること が多く, 圧密降伏応力は, その地層が今までに経 験した最大有効応力によって決まるとされること が多い。図 3 の事例にみられる状況は, 泥質層の 圧密降伏応力が，層内で鉛直方向に均一になると は限らないことを意味している。また，この図に 示されている経緯を経た難透水性の泥層は, さら なる排水と地盤沈下に寄与するだけの変形をする ことが可能である。すなわち, 一度帯水層中の水 理ポテンシャルを下げたことによって地盤沈下が 発生したということに基づき, 今一度帯水層中の 水理ポテンシャルを同じ状態にまで低下させて も，すでに泥質層からの排水が行われたために永 久変位を伴う地盤沈下は起きないと主張すること は適切ではない場合があることを意味している。 技術的な観点からは，仮に今後の地下水利用を想

\section{Pore pressure, $\mathrm{kPa}$}

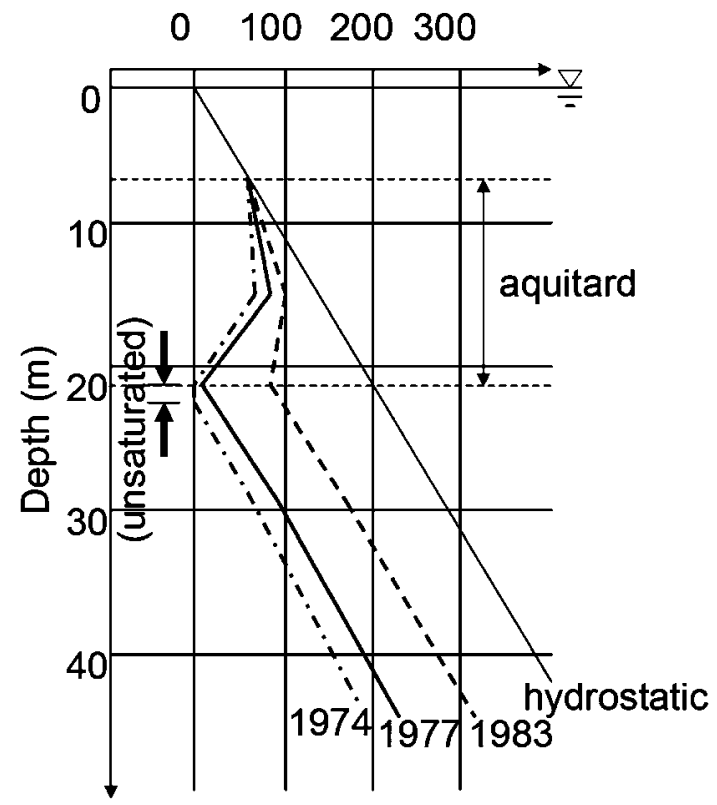

図 3 東京の神明観測井データを用いた難透水層中の 間隙水圧変化の評価例（愛知，2009）。
定し, 発生するであろう地盤沈下量を精度良く評 価するためには，検討する領域における泥質層内 の間隙水圧プロファイルの経時変化を高い空間解 像度で解析することが重要になるということがで きる。一方で, 带水層システムは広域的に連続し ていることが一般的であるため, 帯水層内の水理 ポテンシャルの変化を検討するためには, 広域地 下水流動を取り扱うことも必要となってくる。

\section{4. 適切な地下水管理に必要な技術開発一ーつ の取り組みー}

ここまでに取りまとめたような経緯に基づく と, これからの地下水の管理はどのようにあるべ きであろうか。実は, この問題は, 極めて難しい 側面を持っている。というのは, 地下水や地下環 境と人間社会との関係を考える上では様々な立場 を取ることが可能であり，それぞれの立場によっ てあり得るべき将来像が違ってくるからである。

様々な立場が取られる問題を考える上で技術的 な観点から重要なことは, 実際にどのようなこと が起こってきているのかを知ること, 今後地下水 利用に対して何らかのアクションをしたときにど のようなことが発生し得るかをできる限り正確に 予測すること, さらには, 実際に起こる現象を精 度良く監視すること, であると考えている。最初 の観点である歴史的な経緯やそこで注目すべき点 のいくつかについては今までに述べてきているの

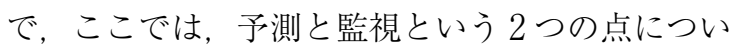
て, 現在我々が行っている研究の一端を紹介して みたい。

まず, 一つめは, 地下水挙動とそれに伴う地盤 変動の再現 · 予測を可能にする数值解析技術の開 発である。地下水挙動と地盤変形との関係につい ては今までに多くの研究がなされており, 要素過 程をかなり正確に表現することが可能なレベルに 達しているといえる。図 3 のデー夕を用いた議論 もこのような考え方に基づいている。しかし，実 問題に適用するためには, 前節にも述べたよう に, 広域的に連続した地下水流動と, 地盤沈下に かかわる変形が主に発生するスケールである難透 水性層内の変形現象を同時に解析する必要があ る。そのために, 我々は, 広域の地下水流動と局 
所で発生する地下水流動・地盤変動を連結して解 析する手法の開発を行っている（愛知, 2009）。 図 4 はその結果の一例であるが, 観測結果を計算 結果が良く再現しているととらえている。なお, 図 4 では, 北川辺観測井の観測井水位が周期的な 変動をしつつ, 年平均ではほとんど変化していな い中で, 周辺の地盤沈下が進行していることが示 されている。この結果は, 帯水層の水理ポテン シャルが 1 年間程度の時間で平均すれば大きな変 化がなく，季節的な利用のみをするような場合で あっても地盤沈下が発生しうることを示してお り，これは，前節で議論した難透水性層中の間隙 水圧変化の評価が重要であることを示している結 果でもある。

もう一つは, 衛星情報の一つである合成開口 レーダを用いて地表面変動を広域的に精度良く知 るという方法である。図 5 の左図は関東地域を対
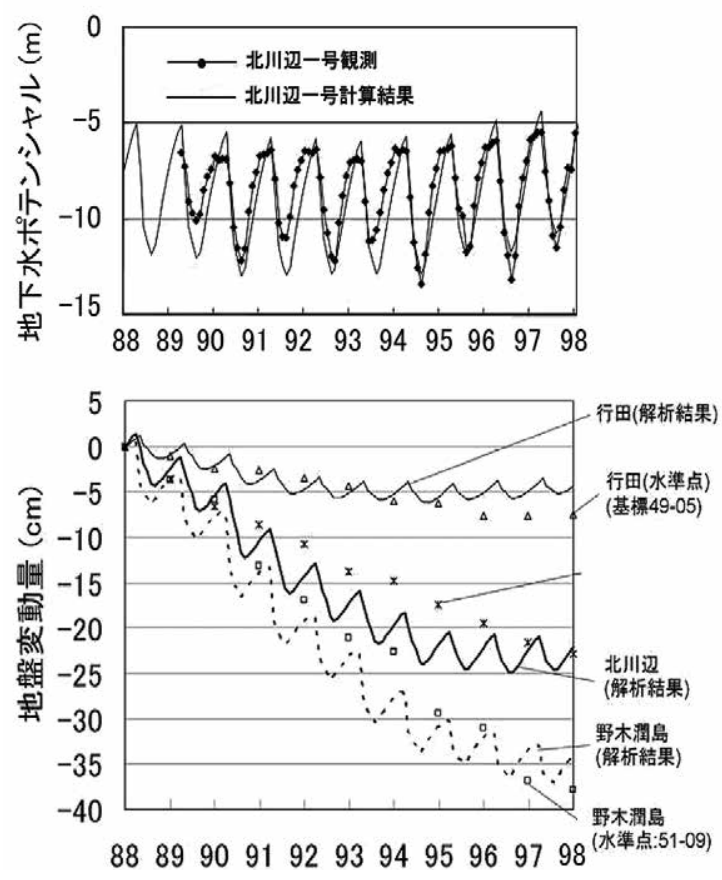

図 4 広域地下水流動と局所地下水流動・地盤変動の 連結解析による解析結果の例。北川辺観測井 (埼 玉県加須市）の井戸水位観測結果と計算結果（左 図）と, 3 つ水準点（行田（埼玉県行田市）, 北川辺 (埼玉県加須市), 野木潤島 (栃木県下都 賀郡野木町)）の水準測量結果と地盤変動量計算 結果（右図）(愛知, 2009）。
象とした観測結果の例, 図 5 の右図は, 九十九里 平野周辺での例であるが, 現地での水準測量結果 と合成開ロレーダに基づく地盤変動監視結果は整 合性が高いことがわかる（出口ほか，2009）。と ころで、図 5 の左図では、東京の下町低地の南部 では，少し地盤が上昇していることが観測されて いる。図 1 に示されている地盤変動からも最近の 地盤の上昇は認められており, この結果も, 水準 測量と合成開ロレーダの監視結果が良く合ってい ることを支持している。

我々は，予測のためのモデリング技術と観測・ 監視技術とを組み合わせ，さらにGISによるデー 夕統合をすることにより, 今後の適切な地下水管 理に必要な技術的な観点からの貢献が可能になる と考えている（Obanawa et al., 2010）。このよう なアプローチを取り込んだうえで, 社会の要請に 対応する技術情報を丁寧に提供していくことがよ り合理性の高い地下水管理に向かう方向性の一つ であろう（図 6 )。

\section{5. 今後考えるべきこと}

地下水は人類にとって主要な淡水資源の一つで あるが，その利用に伴い地表及び地下の環境はさ まざまに変化する。地下水は, 平常時の安定した 水資源でありうるとともに, 緊急時の重要な水資 源となり得る。したがって, どのような目的で地 下水利用を行うにあたっても，そのことによって 発生する変化と環境への影響については, 十分に 認識したうえで行動を起こす必要がある。また, 地下水を含め, 水は人類並びに生態系に共有の資 源であり，地域社会がどのような将来像を「ある べきもの」と考えるかによっても，目指す方向は 変わってくるはずである。このことは，いわゆる 科学・技術的な観点のみから地下水管理のありう る姿を議論することには限界があることを示して いる。一方で，科学・技術的な観点からできるだ け正確な情報を適切に提示することは, 地域社会 が積極的に課題を検討し，起こりうる結果につい て理解をしながら一つ一つ納得していくことに対 して重要な貢献をするはずである。さらには, 多 くの人が現状を理解し, 今後の活動に伴う変化に ついて知ることが可能になる状況を構築すること 

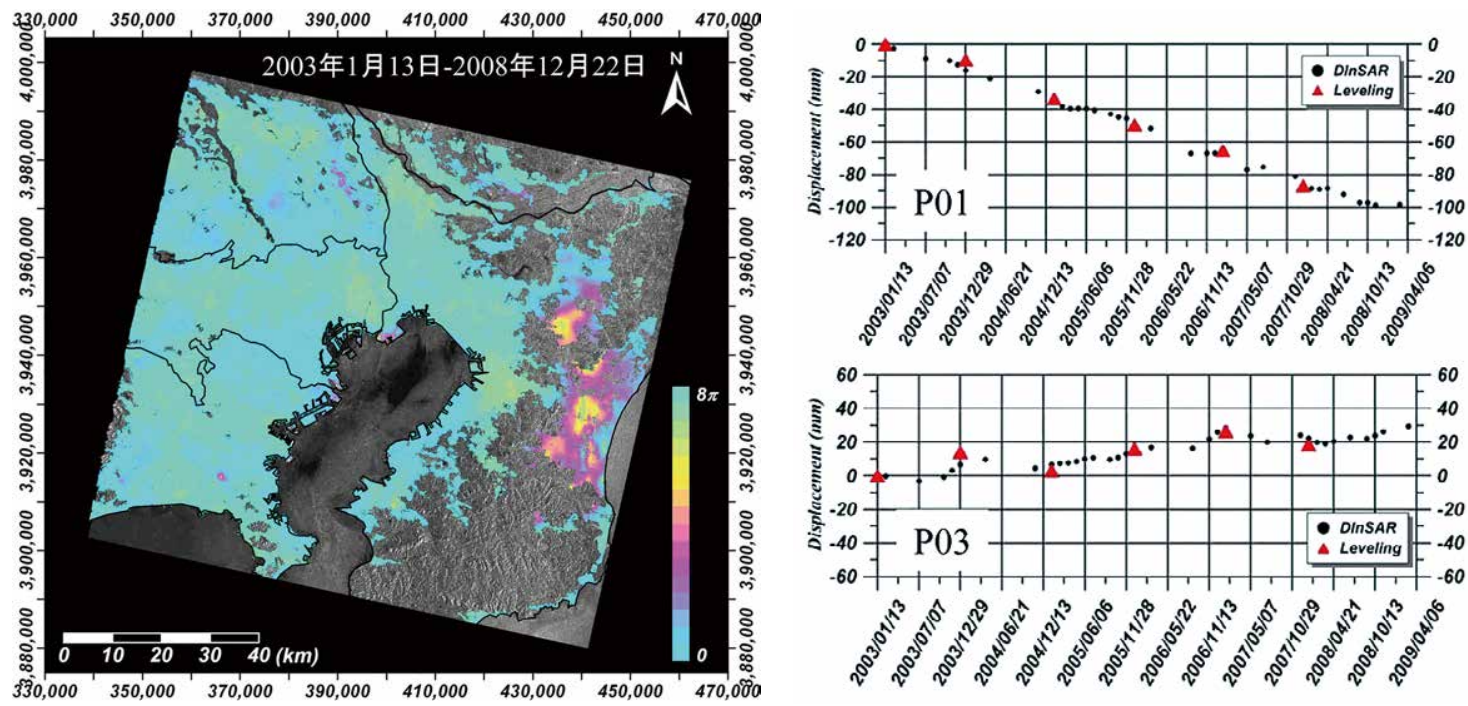

図 5 合成開ロレーダを用いた地盤変動観測の例。左図は関東地域における観測結果を示す。カラーバーは, 衛星から地表面への視線方向の距離の变化量を示しており $8 \pi$ は約 $11.2 \mathrm{~cm}$ の変動を表す。0 から $8 \pi$ に向かって色が変わる場合は，地表面が衛星から遠ざかっており，8 合には地表面が衛星に近づいていることを意味する。九十九里平野での地盤沈下や東京の江東地域での わずかな地盤の膨張が認められる。右図は九十九里地域の 2 点（千葉県山武郡大網白里町 (P01), 千 葉県長生郡一宮町 (P03) ) での水準測量と合成開ロレーダ観測結果の比較を示す。綎軸は 2003 年 1 月 13 日以降の地盤変動量, 横軸は時間経過を表す。赤の三角が水準測量, 黒点が衛星からの観測結果。 出口ほか（2009）に基づき作成。

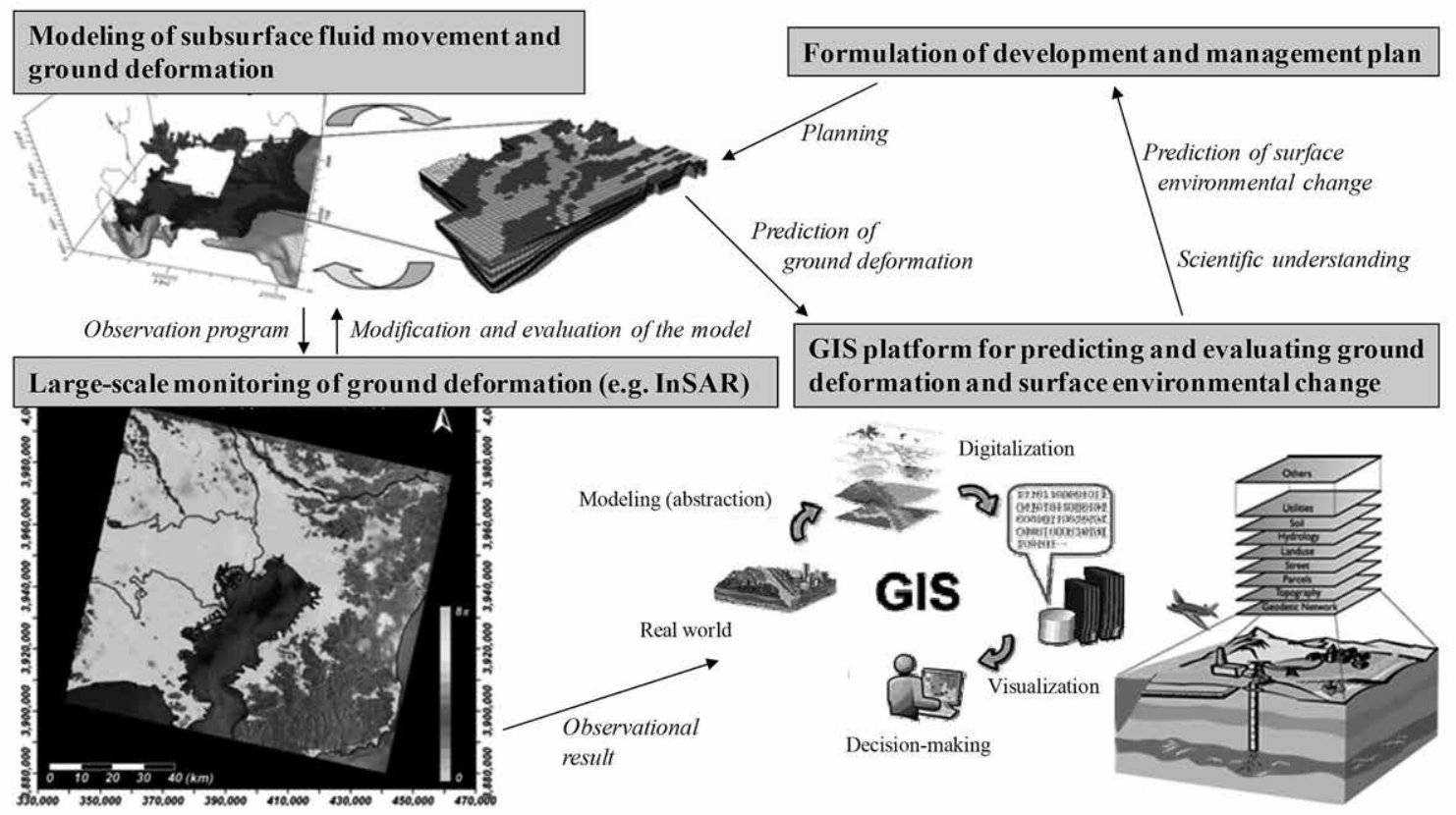

図 6 数値モデリングと観測技術，GIS を統合した地下水管理のあり方の一例（Obanawa et al., 2010）。 
も重要である。具体的には，前節で述べたような 地盤変動観測結果の提供や, 今までも行われてき ている地盤沈下観測井による帯水層中の水理ポテ ンシャル変化の計測, 水準測量や地盤沈下計測結 果の地域社会への公表といった活動を継続してい くことが不可欠であろう。これらの情報の適切な 提供と, 地域社会における議論, 科学・技術的な 観点からの助言が双方向的になされ, 地域社会が 納得したうえで地下水の保全・利用とそのための 管理を行うという方向性が, これからのあるべき 姿の一つではないだろうか。

\section{参考文献}

愛知正温（2009）：広域地下水流動を考慮した地盤変動 モデリング：関東平野を対象として。一般社団法人 日本応用地質学会平成21年シンポジウム予稿集, 6063.

遠藤 毅・小笠原弘信（1976）：沖積低地における間ゲ キ水圧変化と地盤沈下の関係について. 昭和50年度 東京都土木技術研究所年報, 165-181.

遠藤 毅・川島真一・川合将文 (2001) : 東京下町低地

に扔ける“ゼロメートル地帯”展開と沈静化の歴史. 応用地質, 42, 74-87.

榧根 勇 (1994)：多摩川水系の地表水と地下水の交流

に関する研究. とうきゅう環境浄化財団研究助成成 果報告書. 310p.

川島真一 (2001): 東京都に抢ける地下水位の経年変化.
基礎工, 29 (11)，77-79.

小林傳司 (2007)：トランス・サイエンスの時代一科学 技術と社会をつなぐー. NTT 出版, 288p.

清水 満・鈴木 尊 (2005) : 地下水の上昇に対する地

下駅の対策工事. 土と基礎, 53 (10), 29-31.

出口知敬・六川修一・松島 潤 (2009): 干渉 SAR の 時系列解析による長期地盤変動計測. 日本リモート センシング学会誌, 29, 418-428.

東京都建設局（2004）：東部低地带の地盤高図. http://

www.kensetsu.metro.tokyo.jp/kasen/gaiyo/pdf_/143.pdf.（2014年 5 月 4 日閲覧）

廣瀬 誠 · 川越 健 · 木谷日出男 (2004)：建設工事 ·

地下構造物と地下水. 平成16年度日本応用地質学会 研究発表会予稿集. P46.

守田 優 (2012): 地下水は語る一見えない資源の危機.

岩波書店. 240p.

Aichi, M., and T. Tokunaga (2008): Land subsidence simulation by a nested modeling scheme to integrate regional groundwater flow and local groundwater flow/land deformation models: a case study from Tokyo and its surrounding. Proceedings of XXXVI IAH Congress, 26 Oct-1 Nov, Toyama, Japan. S31, p215-1.

Obanawa, H., T. Tokunaga, S. Rokugawa, T. Deguchi and T. Nakamura (2010): Land subsidence at the Kujukuri Plain in Chiba Prefecture, Japan: Evaluation and monitoring environmental impacts. IAHS Publications., 339, 293-298.

（受付：2014年 5 月 5 日, 受理 : 2014年12月22日) 